\title{
RAPD and ISSR-assisted identification and development of three new SCAR markers specific for the Thinopyrum elongatum $\mathrm{E}$ (Poaceae) genome
}

\author{
G.H. Xu*, W.Y. Su*, Y.J. Shu, W.W. Cong, L. Wu and C.H. Guo \\ Key Laboratory of Molecular Cytogenetics and Genetic \\ Breeding of Heilongjiang Province, College of Life Science and Technology, \\ Harbin Normal University, Harbin, China \\ *These authors contributed equally to this study. \\ Corresponding author: C.H. Guo \\ E-mail: kaku2008@hotmail.com
}

Genet. Mol. Res. 11 (2): 1741-1751 (2012)

Received August 1, 2011

Accepted December 26, 2011

Published June 29, 2012

DOI http://dx.doi.org/10.4238/2012.June.29.7

\begin{abstract}
Diploid Thinopyrum elongatum, a wild relative of wheat, contains many agronomically desirable traits and has potential for increasing genetic variability and introducing desirable characters in this crop. Few molecular markers are available for rapid screening of $T$. elongatum genome segments in the wheat genetic background. We used 36 RAPD primers and 33 ISSR primers to screen for polymorphisms in the common wheat variety Chinese Spring and in T. elongatum. Two RAPD markers and one ISSR marker, designated OPF03 ${ }_{1407}, \mathrm{LW} 10_{1487}$ and $\mathrm{UBC} 841_{701}$, were identified and were specific for the T. elongatum $\mathrm{E}$ genome. Three pairs of primers flanking these specific sequences were designed to produce SCAR markers. All three SCAR markers were $T$. elongatum E genome-specific. Two of these SCAR markers, $\mathrm{SCAR}_{807}$ and $\mathrm{SCAR}_{577}$, were present in all seven $T$. elongatum chromosomes, while $\mathrm{SCAR}_{839}$ was specific for T. elongatum chromosomes $2 \mathrm{E}$ and $3 \mathrm{E}$.
\end{abstract}


These newly developed SCAR markers should be useful for detecting alien genome chromatin or chromosome segments in the genetic background of common wheat.

Key words: ISSR; RAPD; Sequence characterized amplification region; Thinopyrum elongatum

\section{INTRODUCTION}

The diploid wheatgrass Thinopyrum elongatum (Host) D.R. Dewey [= Lophopyrum elongatum (Host) Á. Löve; = Elytrigia elongatum (Host) Nevski; = Agropyron elongatum (Host) Beauv.] ( $2 \mathrm{n}=2 \mathrm{x}=14$; EE genome) is a wild relative of wheat, with many superior characters, such as high protein content, resistance to biotic stress caused by pathogens and pests (Shukle et al., 1987; Sharma et al., 1989; Yang and Ren, 2001; Shen et al., 2004), and tolerance to abiotic stress caused by drought and salinity. Therefore, T. elongatum has been used in breeding programs for improvement of wheat, and several agronomically important genes have been successfully identified in the T. elongatum genome in past decades. These genes include yellow dwarf virus resistance (Sharma et al., 1995), leaf rust resistance (Sharma and Knott, 1966), yellow rust resistance (Ma et al., 2000), and fusarium head blight (FHB) resistance (Jauhar and Peterson, 2000; Oliver et al., 2005; Shen and Ohm, 2007). Other useful agronomical traits are also discovered in Thinopyrum intermedium, including resistance to abiotic stresses such as drought (Roundy, 1985) and salinity (Omielan et al., 1991; Deal et al., 1999).

Hybridization and introgression are a potentially effective method for the introduction of those desirable genes into wheat. However, for this approach to be successful it is important to develop tools for identifying alien T. elongatum $\mathrm{E}$ genomic sequences in recombinant plants derived from wheat-Thinopyrum crosses. While agronomic traits and biochemical analysis have been used to map valuable genes in T. elongatum, these methods have poor reproducibility and are not suited for the selection of important traits. Some genetic methods, such as chromosome banding and in situ hybridization, have also been used to screen for T. elongatum genes in the genetic background of common wheat. However, these techniques are laborintensive and technically demanding requiring advanced skills, and therefore cannot be easily adopted into breeding programs that require rapid screening of large numbers of genotypes.

With recent advances in molecular biology, DNA molecular markers are being increasingly employed in genetic and breeding research in wheat. Restriction fragment length polymorphisms (RFLP) have been successfully used as molecular markers in plant genetic studies. However, RFLP analysis requires large quantities of DNA, and the procedure is time-consuming and technically demanding, and is therefore not well suited for large-scale plant screenings in breeding programs. In recent years, plant breeders have turned to polymerase chain reaction (PCR)-based technologies in the hope of finding an easier way to detect alien genes in recombinant introgression lines. Many PCR-based DNA markers have been developed, including randomly amplified polymorphic DNA (RAPD), amplified fragment length polymorphism (AFLP), simple sequence repeat (SSR), expressed sequence tag (EST), and inter-simple sequence repeats (ISSR). Among these DNA markers, RAPD and ISSR are relatively simple to use and are highly effective in plant fingerprinting and phylogenetic studies, which require no prior knowledge of sequence information. However, they have the drawback of poor re- 
producibility and stability. Sequence characterized amplification region (SCAR) markers with designed primers significantly improve the reproducibility and reliability of PCR-based assays (Hernández et al., 1999). They are notably relatively inexpensive and straightforward to use, because additional treatment after PCR is unnecessary. They are therefore considered to be more suitable molecular markers for crop breeding and genetic analysis. Furthermore, SCAR markers have relatively long sequences and can produce more specific and prominent band signals (Chowdhury et al., 2001). Recently, SCAR markers have been developed for analysis of the rye R genome and the Agropyron P genome (Vaillancourt et al., 2008; Liu et al., 2008; Wu et al., 2010), but such markers have not been reported for the T. elongatum E genome.

In this study, we have used the RAPD and ISSR methods to screen T. elongatum E genome-specific molecular markers, and have successfully developed SCAR markers. These novel SCAR markers allowed the detection of T. elongatum E genome-derived alien chromatin or chromosome segment in the common wheat genetic background. To our knowledge, this is the first report of T. elongatum E genome-specific SCAR markers that are present in all T. elongatum chromosomes and suitable for the detection of T. elongatum DNA sequences in wheat.

\section{MATERIAL AND METHODS}

\section{Plant material}

Plant materials used for PCR amplification included the common wheat cultivar Chinese Spring, T. elongatum (2x), T. elongatum (4x), and wheat-T. elongatum disomic addition lines (1E-7E). The common wheat cultivar Chinese Spring (hereafter abbreviated as CS) was propagated by our own laboratory. T. elongatum $(2 \mathrm{x})$ and the wheat-T. elongatum disomic addition lines (1E-7E) were provided by the National BioResource Project, Japan (NBRP-Wheat). T. elongatum $(4 \mathrm{x})$ was provided by the Chinese Academy of Agricultural Sciences. The $\mathrm{F}_{1}$ and $\mathrm{F}_{2}$ hybrids from the cross between the CS-3E disomic addition line and the CS-2C disomic addition line (containing a pair of $2 \mathrm{C}$ chromosomes from Aegilops cylindrica) were developed in our own laboratory. The CS-2C disomic addition line was also provided by the NBRP-Wheat.

\section{Genomic DNA extraction}

Genomic DNA was extracted from $0.1 \mathrm{~g}$ fresh young leaves, using a modified cetyl trimethylammonium bromide (CTAB) extraction protocol (Doyle and Doyle, 1990). The DNA was dissolved in $50 \mu \mathrm{L}$ sterilized double-distilled water. Quality of DNA was checked on $0.8 \%$ agarose gels, and DNA concentration was determined using a spectrophotometer (Helios Betra, England).

\section{RAPD and ISSR marker analysis}

Thirty-six decamer random primers and 33 ISSR primers were used to screen the wheat and T. elongatum. RAPD amplification reactions were performed in a $20-\mu \mathrm{L}$ reaction mixture containing $30 \mathrm{ng}$ template DNA, $0.4 \mu \mathrm{M}$ primers, $0.2 \mathrm{mM}$ dNTP, $0.5 \mathrm{U}$ rTaq polymerase, and $2.0 \mu \mathrm{L}$ 10X PCR buffer (containing $10 \mathrm{mM}$ Tris- $\mathrm{HCl}, \mathrm{pH} 8.3,50 \mathrm{mM} \mathrm{KCl}, 1.5$ $\mathrm{mM} \mathrm{MgCl}$ ), with the PCR program of 5 min at $94^{\circ} \mathrm{C}, 45$ cycles of $30 \mathrm{~s}$ at $94^{\circ} \mathrm{C}, 45 \mathrm{~s}$ at $36^{\circ} \mathrm{C}$, $1 \mathrm{~min}$ at $72^{\circ} \mathrm{C}$, and a final 10 -min extension at $72^{\circ} \mathrm{C}$. ISSR amplification reactions were per- 
formed in a $20-\mu \mathrm{L}$ reaction mixture containing $50 \mathrm{ng}$ template DNA, $0.4 \mu \mathrm{M}$ primers, $0.2 \mathrm{mM}$ dNTP, $0.5 \mathrm{U} r$ Taq polymerase, and $2.0 \mu \mathrm{L} \mathrm{10X} \mathrm{PCR} \mathrm{buffer} \mathrm{(containing} 10 \mathrm{mM}$ Tris-HCl, $\mathrm{pH}$ $8.3,50 \mathrm{mM} \mathrm{KCl}, 1.5 \mathrm{mM} \mathrm{MgCl}$ ), with the PCR program of $4 \mathrm{~min}$ at $94^{\circ} \mathrm{C}, 42$ cycles of $1 \mathrm{~min}$ at $94^{\circ} \mathrm{C}, 1 \mathrm{~min}$ at $52^{\circ} \mathrm{C}, 2 \mathrm{~min}$ at $72^{\circ} \mathrm{C}$, and a final 7 -min extension at $72^{\circ} \mathrm{C}$. PCR product was then separated on a $1.2 \%$ agarose gel in $1 \mathrm{X}$ TAE buffer. The gels were stained with ethidium bromide and visualized with a gel-scanning imager (Gel Doc-2000, Bio-Rad, USA) to identify polymorphism among the screening images.

\section{Cloning and sequencing of the specific RAPD and ISSR products}

The RAPD and ISSR amplification products were excised from 1.2\% agarose gels and purified by a gel extraction kit (TaKaRa Bio Inc., Otsu, Dalian, China). The purified products were ligated into the pMD18-T vector (TaKaRa Bio Inc.), and then introduced into the Escherichia coli JM109 competent cells by heat shock transformation. Insert-containing positive clones were identified by PCR analysis using RV-M and M13-47 primers. The selected clones were sequenced in both directions by Sangon Biotech (Shanghai, China).

\section{SCAR primer design and amplification}

The sequences of the RAPD and ISSR product were blasted against the NCBI NR database. Primers were then designed flanking the inserts to convert them into SCAR markers, and the parameters used for primer design were: 1) primer length of 18-26 nt with the optimal length of 22 nt; 2) annealing temperature of $50^{\circ}-60^{\circ} \mathrm{C}$ with the optimum being $58^{\circ} \mathrm{C}$; 3) percentage $\mathrm{GC}$ content in the range of $40-55 \%$, and 4 ) product size of $400-800 \mathrm{bp}$. The SCAR amplification reactions were performed in a $20-\mu \mathrm{L}$ reaction mixture containing $50 \mathrm{ng}$ template DNA, $0.2 \mu \mathrm{M}$ of each primer, 0.2 $\mathrm{mM}$ dNTP, $1 \mathrm{U} r \mathrm{Taq}$ polymerase, and $2.0 \mu \mathrm{L} 10 \mathrm{X}$ PCR buffer (containing $10 \mathrm{mM}$ Tris-HCl, $\mathrm{pH} 8.3$, $50 \mathrm{mM} \mathrm{KCl}, 1.5 \mathrm{mM} \mathrm{MgCl}_{2}$ ), with the PCR program of $5 \mathrm{~min}$ at $94^{\circ} \mathrm{C}, 35$ cycles of $30 \mathrm{~s}$ at $94^{\circ} \mathrm{C}, 30$ s at $52-60^{\circ} \mathrm{C}, 1 \mathrm{~min}$ at $72^{\circ} \mathrm{C}$, and a final 10 -min extension at $72^{\circ} \mathrm{C}$. The product was separated on a $0.8 \%$ agarose gel, stained with ethidium bromide, and visualized with gel scan imaging.

\section{RESULTS}

\section{Development of RAPD and ISSR markers from the T. elongatum genome}

Thirty-six RAPD primers (decamer oligonucleotides) and 33 ISSR primers were used to screen the panel comprised of three varieties or lines, including the common wheat CS, the diploid T. elongatum ( $2 \mathrm{x}$ ) and the tetraploid T. elongatum (4x). Stable products were successfully amplified with 20 RAPD primers and 26 ISSR primers from the three DNA samples screened. Six of the RAPD and eight of the ISSR primers are specific for the T. elongatum E genome, of which two RAPD and one ISSR primers were further investigated. The products with the two RAPD primers OPF03 and LW10 were approximately 1400 and 1500 bp in length (Figure 1A and B), respectively, which were present in both the $2 \mathrm{x}$ and the $4 \mathrm{x}$ T. elongatum but absent in the common wheat. Similarly, the ISSR primer UBC841 amplified a 700-bp product from the T. elongatum E genome but yielded no products from CS (Figure 1C). These results indicated that these markers were specific for the T. elongatum $\mathrm{E}$ genome, and could be used for detecting the T. elongatum $\mathrm{E}$ genome in the common wheat genetic background. 

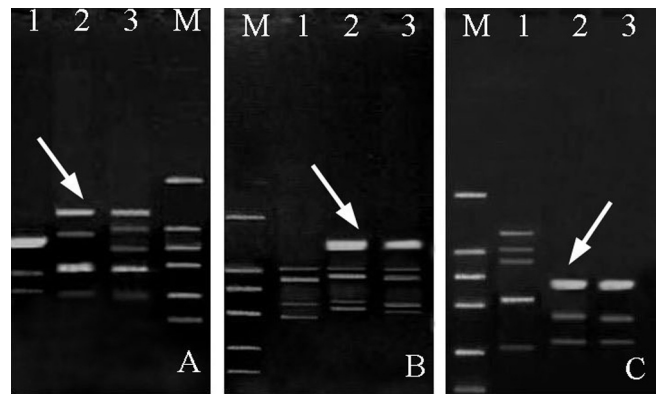

Figure 1. The amplification products of RAPD and ISSR primers in Chinese Spring (CS), Thinopyrum elongatum (2x) and T. elongatum (4x). A. RAPD primer OPF03; B. RAPD primer LW10; C. ISSR primer UBC841. Lane $1=$ Common wheat CS; lane $2=T$. elongatum (2x); lane $3=T$. elongatum (4x); lane $M=$ DL2000 marker $(8.5 \mathrm{~cm} \times 5.07 \mathrm{~cm}, 300$ dpi).

\section{Sequence analysis of cloned fragments}

The T. elongatum E genome-specific RAPD and ISSR products were cloned and sequenced. The results revealed that the OPF03, LW10 and UBC841-amplified fragments were 1407, 1487 and $701 \mathrm{bp}$ in length, respectively (Figure 2A, B and C). They are therefore named as $\mathrm{OPF} 03_{1407}, \mathrm{LW} 10_{1487}, \mathrm{UBC} 841_{701}$, respectively. A homology search showed that $\mathrm{OPF} 03_{1407}$ had no sequence match in the NR NCBI database, while LW10 ${ }_{1487}$ and UBC841 701 were homologous to part of the Triticum aestivum chromosome 3B-specific BAC sequences. The three E genome-specific nucleotide sequences were submitted to GenBank and registered with the accession Nos. JF261099, JF267715 and JF267716.
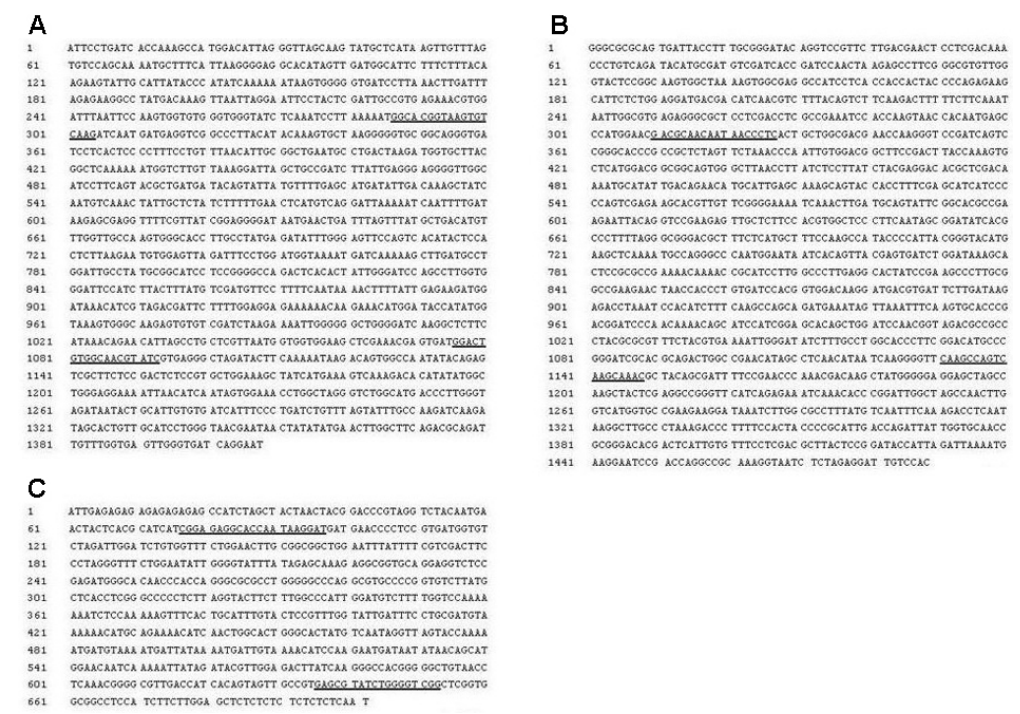

Figure 2. Consensus sequence of Thinopyrum elongatum-specific DNA fragments produced by RAPD and ISSR markers. A. Nucleotide sequence of RAPD marker OPF03 ${ }_{1407}$. B. Nucleotide sequence of RAPD marker LW $10_{1487}$. C. Nucleotide sequence of ISSR marker UBC841 ${ }_{701}$. Underline indicates location of $\mathrm{SCAR}_{807}, \mathrm{SCAR}_{839}$ and $\mathrm{SCAR}_{577}$ markers, respectively $(8.5 \mathrm{~cm} \times 6.63 \mathrm{~cm}, 300 \mathrm{dpi})$. 


\section{Conversion of RAPD and ISSR markers into SCAR markers}

In order to increase the specificity and reproducibility of the RAPD and ISSR markers, corresponding SCAR markers were designed based on the sequences of the RAPD and ISSR markers and used to validate the utility of the molecular markers in wheat, T. elongatum, and wheat-T. elongatum disomic addition lines (1E-7E). PCR amplification showed that the predicted bands of 807, 839 and 577 bp existed in the 2x and 4x T. elongatum as well as in the wheat-T. elongatum addition lines, but not in the common wheat CS. Thus, the three RAPD and ISSR markers were successfully converted into SCAR markers (Figure 3), which are named as $\mathrm{SCAR}_{807}, \mathrm{SCAR}_{839}$ and $\mathrm{SCAR}_{577}$ (Table 1), respectively. Chromosome localization analysis showed that $\mathrm{SCAR}_{839}$ is located on chromosomes $2 \mathrm{E}$ and $3 \mathrm{E}$. Using the same method, $\mathrm{SCAR}_{807}$ and $\mathrm{SCAR}_{577}$ were found to exist in $2 \mathrm{x}$ and $4 \mathrm{x}$ T. elongatum, and all seven wheat- $T$. elongatum disomic addition lines. This result suggested that these two SCAR markers are present in all chromosomes of T. elongatum.

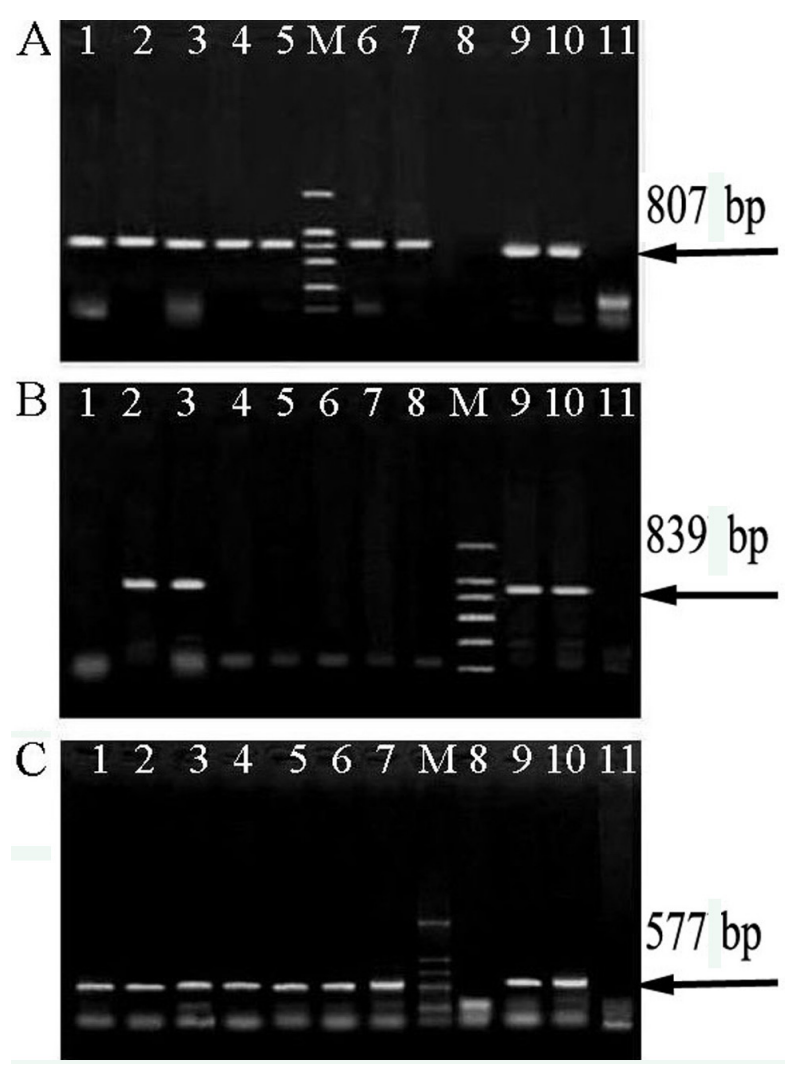

Figure 3. PCR amplification of Chinese Spring-1E-7E disomic addition (CS-1E-7E DA) lines, CS-2C DA line, Thinopyrum elongatum $(2 \mathrm{x})$, and T. elongatum $(4 \mathrm{x})$ with RAPD-SCAR and ISSR-SCAR primers. A. RAPD$\mathrm{SCAR}_{807}$ primer. B. RAPD-SCAR ${ }_{839}$ primer. C. ISSR-SCAR ${ }_{577}$ primer. Lane $1=\mathrm{CS}-1 \mathrm{E} \mathrm{DA}$; lane 2 = CS-2E DA; lane $3=\mathrm{CS}-3 \mathrm{E}$ DA; lane $4=\mathrm{CS}-4 \mathrm{E}$ DA; lane $5=\mathrm{CS}-5 \mathrm{E}$ DA; lane $6=\mathrm{CS}-6 \mathrm{E}$ DA; lane $7=\mathrm{CS}-7 \mathrm{E}$ DA; lane $8=$ $\mathrm{CS}$; lane $9=$ T. elongatum $(2 \mathrm{x})$; lane $10=T$. elongatum $(4 \mathrm{x})$; lane $11=\mathrm{CS}-2 \mathrm{C} \mathrm{DA}$; lane $M=\mathrm{DL} 2000$ marker $(8.5$ $\mathrm{cm} \times 12.2 \mathrm{~cm}, 300 \mathrm{dpi})$. 
Table 1. Characteristics of the SCAR markers developed for the E genome of Thinopyrum elongatum.

\begin{tabular}{|c|c|c|c|c|c|}
\hline RAPD ID & RAPD primer (5'-3') & SCAR ID & SCAR primer $\left(5^{\prime}-3^{\prime}\right)$ & Size (bp) & $\operatorname{Tm}\left({ }^{\circ} \mathrm{C}\right)$ \\
\hline$\overline{\mathrm{OPF} 03}$ & CCTGATCACC & $\begin{array}{l}\text { OPF03-1407-F } \\
\text { OPF03-1407-R }\end{array}$ & $\begin{array}{l}\text { GGCACGGTAAGTGTCAAG } \\
\text { GATACGTTGCCACAGTCC }\end{array}$ & 807 & 57 \\
\hline LW10 & ACCTTTGCGG & $\begin{array}{l}\text { LW10-1487-F } \\
\text { LW10-1487-R }\end{array}$ & $\begin{array}{l}\text { GACGCAACAATAACCCTC } \\
\text { GTTTGCTTGACTGGCTTG }\end{array}$ & 839 & 54 \\
\hline UBC841 & GAGAGAGAGAGAGAGAGC & $\begin{array}{l}\text { UBC } 841-701-\mathrm{F} \\
\text { UBC841-701-R }\end{array}$ & $\begin{array}{l}\text { CGGAGAGGCACCAATAAGGAT } \\
\text { CCGACCCCAGATACGCTC }\end{array}$ & 577 & 58 \\
\hline
\end{tabular}

RAPD = randomly amplified polymorphic DNA; SCAR = sequence characterized amplification region; $\mathrm{Tm}=$ melting temperature.

\section{Identification of hybrid progenies with SCAR markers}

To identify the utility of the three SCAR markers, $\mathrm{SCAR}_{807}, \mathrm{SCAR}_{839}$ and $\mathrm{SCAR}_{577}$ were used to screen the $\mathrm{F}_{1}$ and $\mathrm{F}_{2}$ progeny derived from the cross between the two disomic addition lines CS-3E and CS-2C. All three SCAR markers were present in the $\mathrm{F}_{1}$ progeny, while in the $\mathrm{F}_{2}$ population the amplification was variable among individual plants (Figure 4A, B and $\mathrm{C}$, respectively). Some $\mathrm{F}_{2}$ lines, with the chromosome number of $2 \mathrm{n}=42$, yielded a single SCAR product. FISH hybridization signals were not shown along the whole chromosome (data not shown), indicating that they were translocation lines, but not substitution lines. Other $\mathrm{F}_{2}$ lines yielded no PCR product, suggesting that they are not translocation lines. Of these $\mathrm{F}_{2}$ lines, 28 of $152 \mathrm{~F}_{2}$ individuals have the chromosome number of $2 \mathrm{n}=42$, eight of 28 individuals gave a single specific amplification product of the three SCAR markers, indicating that the frequency of translocation is at least $5.26 \%$ in the $\mathrm{F}_{2}$ lines.

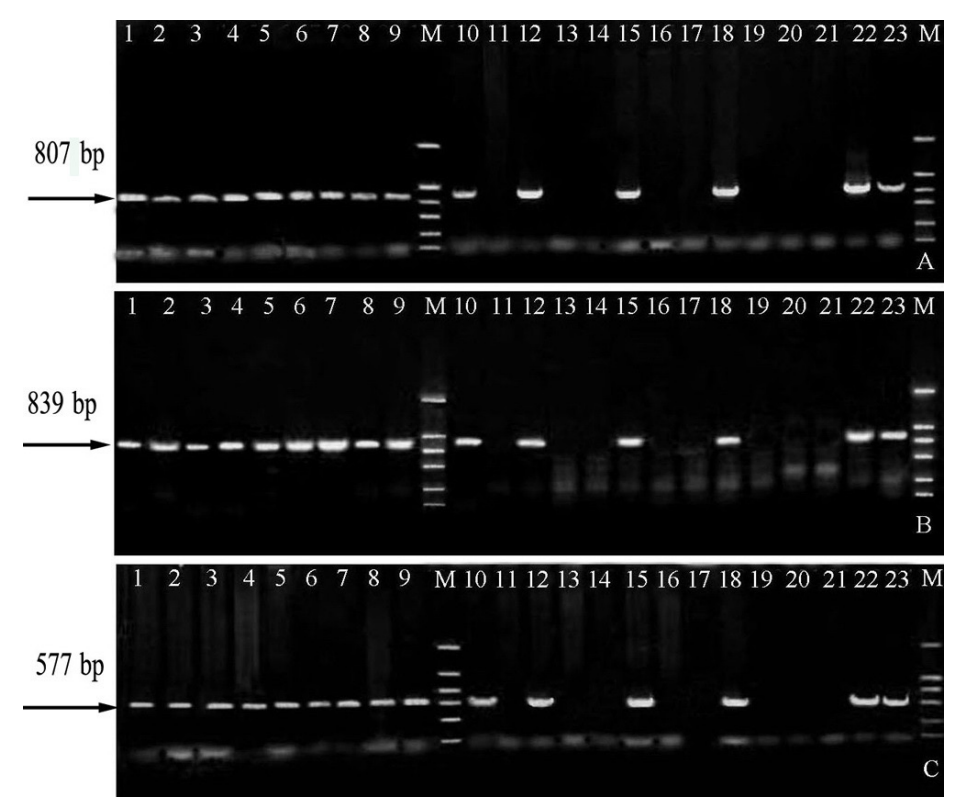

Figure 4. The amplification results of three markers $\operatorname{SCAR}_{807}(\mathbf{A}), \operatorname{SCAR}_{839}(\mathbf{B})$ and $\operatorname{SCAR}_{577}(\mathbf{C})$ primers in $\mathrm{F}_{1}, \mathrm{~F}_{2}$ progenies. Lanes 1-9 $=\mathrm{F}_{1}$ progenies crossed by Chinese Spring-3E disomic addition (CS-3E DA) and CS-2C DA; lanes $10-19=\mathrm{F}_{2}$ progenies selfcrossed by $\mathrm{F}_{1}$ progenies; lane $20=\mathrm{CS}$; lane $21=\mathrm{CS}-2 \mathrm{C} \mathrm{DA}$; lane $22=$ Thinopyrum elongatum (2x); lane $23=$ T. elongatum (4x); lane $M=$ DL2000 marker $(8.5 \mathrm{~cm} \times 7.16 \mathrm{~cm}, 300 \mathrm{dpi})$. 


\section{DISCUSSION}

T. elongatum is a wild relative of wheat, and contains a large number of genes for desirable traits that are potentially useful for wheat improvement (Knott et al., 1977; Friebe et al., 1996; Prins et al., 1997; Reynolds et al., 2001). Researchers have identified many potential genes conferring stress tolerance and resistance to a number of wheat diseases and pests, which makes T. elongatum a rich genetic resource related to wheat. The major FHB resistance gene, Fhb1, was identified by Shen and Ohm (2006) from the homologous group 7, based on evaluation of a series of CS-T. elongatum chromosome substitution lines. A genetic map of chromosome 7E was developed and two resistance loci (leaf rust resistance gene $\operatorname{Lr} 19$ and FHB resistance QTL) were mapped to chromosome $7 \mathrm{E}$ by using a population of $237 \mathrm{~F}_{7: 8}$ recombinant inbred lines derived from a cross between two Thatcher-L. ponticum substitution lines (Zhang et al., 2011). The wheat stripe rust disease resistance gene $\mathrm{YrE}$ was located on chromosome $3 \mathrm{E}$ from T. elongatum, and the introduction of genes from the T. elongatum $3 \mathrm{E}$ has improved the resistance of common wheat to salinity stress (Ma et al., 1999). Li et al. (1998) reported that the chromosomes 4E and $6 \mathrm{E}$ of $T$. elongatum carry the genes conferring tolerance to phosphorus deficiency stress. Thus, T. elongatum offers a great potential to wheat breeding programs by contributing genes for many desirable traits. Integration of small alien chromosome segments with excellent genes into the wheat genome is significant for wheat improvement.

Small alien chromosomal segments, which are most desirable in wheat breeding, are difficult to identify using cytological methods. This probably explains the recent interest in developing molecular markers to identify T. elongatum introgressions in the wheat genome. Liu et al. (1998) developed specific RAPD markers for 1E (OPE05 ${ }_{1300}$ and OPF03 ${ }_{700}$ ) and 3E (OPF15 $\left.{ }_{400}\right)$ chromosomes of T. elongatum. You et al. (2003) transferred the wheat SSR into T. elongatum and developed a T. elongatum-specific SSR marker Xgwm325- ${ }_{100 \mathrm{bp}}$. Mullan et al. (2005) developed $T$. elongatum-specific EST-SSR markers based on wheat EST information. Furthermore, Chen et al. (2007) designed resistance gene analog (RGA) primers to detect the resistance gene analog polymorphisms, and established a set of intact L. elongatum (T. elongatum) chromosome-specific RGA polymorphism markers. Zhang et al. (2008) developed 28 specific AFLP markers for T. elongatum, and converted 4 AFLP markers into reliable sequence tagged site (STS) markers. However, there were some drawbacks with these developed markers, which limited their application in breeding programs. For example, the size of SSR and STS markers is small, ranging from 100 to $350 \mathrm{bp}$, making them relatively difficult to detect. Also, it is difficult to develop SSR markers in species of unknown genome sequence, and few SSR markers are available for T. elongatum. In addition, the detection of SSR polymorphisms relies on the use of polyacrylamide gel electrophoresis to separate the product, and silver staining to visualize the DNA bands. RAPDs have poor reproducibility, while the RGA markers are species-specific, which would limit their use in common and related species. Therefore, reproducible, fast and cost-effective molecular markers common for the T. elongatum E genome will be valuable tools for wheat improvement. In this study, the common wheat CS and the $2 \mathrm{x}$ and $4 \mathrm{x}$ T. elongatum were used for screening DNA markers, and three SCAR markers specific to T. elongatum were obtained. We have also checked the applicability of the resulting three markers for distinguishing CS disomic addition lines, which is CS-2C with a pair of $2 \mathrm{C}$ chromosomes from A. cylindrica with T. elongatum chromosomes, because a breeding program using these plant materials is being conducted in our laboratory. The marker present in $T$. elongatum but absent in CS and CS-2C would be applicable to the program. Our BLAST search of 
three SCAR markers showed that all SCAR markers match BAC clones or unknown regions with multiple hits, suggesting their origin from highly repetitive sequences of the genome. There are many highly repetitive regions in wheat and its relative species, and they are widely used as sources of molecular markers in wheat genetic breeding. Chromosome localization analysis in wheat, $T$. elongatum, and derivatives of their cross indicated that the $\mathrm{SCAR}_{807}$ and $\mathrm{SCAR}_{577}$ markers were located on all chromosomes of T. elongatum, making them potentially very useful for detecting $\mathrm{E}$ genome of T. elongatum in a common wheat genetic background. The $\mathrm{SCAR}_{839}$ marker could be used for targeting chromosomes $2 \mathrm{E}$ and $3 \mathrm{E}$ in the derivatives of wheat-T. elongatum crosses.

To test the usefulness of the SCAR markers, we employed the markers to identify translocation lines that might contain T. elongatum-derived alien chromatin. For this study, we selected the $\mathrm{F}_{2}$ lines (including $2 \mathrm{n}=42$ ) because it would be relatively easy to screen for translocation lines preliminarily in this population without the use of other biological techniques and methods. If the SCAR-PCR result is positive, we can then use other techniques and methods to determine the size and position of the translocated fragment. Our results indicated that these SCAR markers can be used to rapidly and accurately identify alien chromosome segments transferred into wheat from T. elongatum. It is worth noting that we have screened 6 RAPD and 8 ISSR primers specific for the T. elongatum E genome, but selected only two RAPD and one ISSR primers in order to obtain a relatively long amplification product. Longer products would increase the possibility for designing SCAR primers, and the resulting SCAR product would be more suitable for agarose gel detection. As a result, from the initial 36 RAPD primers and 33 ISSR primers, we successfully obtained three SCAR markers, with their size ranging from 577 to $839 \mathrm{bp}$, which are suitable for PCR-based detection of the $T$. elongatum E genome. The whole SCAR marker development process was highly efficient.

In summary, we have developed two RAPD markers and one ISSR marker from the T. elongatum E genome, and converted them into three SCAR markers. These SCAR markers were specific for the T. elongatum E genome, two of which were distributed across all the $T$. elongatum chromosomes, and which could be used widely in the detection of derivatives from wheat-T. elongatum crosses. These markers would therefore be useful to wheat breeders for improvement of wheat utilizing genetic resources from the T. elongatum E genome.

\section{ACKNOWLEDGMENTS}

We wish to thank Dr. M.B. Wang (CSIRO Plant Industry) for review and positive criticism of our manuscript. Thinopyrum elongatum (2x), the CS-2C disomic addition line and the wheat-T. elongatum disomic addition lines (1E-7E) were obtained from the National BioResource Project (NBRP)-Wheat. Research supported by the International S\&T Cooperation Program of China (\#2009DFA32470), The Key Technology R\&D Program of Heilongjiang Province of China (\#GA08B104), the 973 Special Program of China (\#2011CB111500), the Aid Program for Science and Technology Innovative Research Team in Higher Educational Institutions of Heilongjiang Province (\#2010TD10), and the Harbin Normal University of China (\#KJTD2011-2).

\section{REFERENCES}

Chen GY, Dong P, Wei YM, He K, et al. (2007). Development of Ee chromosome specific RGAP markers for Lophopyrum elongatum (Host) A.Löve in wheat background by using resistance gene analog polymorphism. Acta Agron. Sin. 33: 1782-1787. 
Chowdhury MA, Andrahennandi CP, Slinkard AE and Vandenberg A (2001). RAPD and SCAR markers for resistance to acochyta blight in lentil. Euphytica 118: 331-337.

Deal KR, Goyal S and Dvorak J (1999). Arm location of Lophopyrum elongatum genes affecting $\mathrm{K}^{+} / \mathrm{Na}^{+}$selectivity under salt stress. Euphytica 108: 193-198.

Doyle JJ and Doyle JL (1990). Isolation of plant DNA from fresh tissue. Focus 12: 13-15.

Friebe B, Jiang J, Raupp WJ, McIntosh RA, et al. (1996). Characterization of wheat-alien translocations conferring resistance to diseases and pests: current status. Euphytica 91: 59-87.

Hernández P, Martín A and Dorado G (1999). Development of SCARs by direct sequencing or RAPD products: a practical tool for the introgression and marker-assisted selection of wheat. Mol. Breed. 5: 245-253.

Jauhar PP and Peterson TS (2000). Toward Transferring Scab Resistance From a Diploid Wild Grass, Lophopyrum elongatum, Into Durum Wheat. In: Proceedings of the 2000 National Fusarium Head Blight Forum. Erlanger, Kentucky, 201-204.

Knott DR, Dvorak J and Nanda JS (1977). The transfer to wheat and homoeology of an Agropyron elongatum chromosome carrying resistance to stem rust. Can. J. Genet. Cytol. 19: 75-79.

Li YJ, Li B, Liu JZ, Li JY, et al. (1998). Chromosomal location of the genes coding for acid phosphatase and alkaline phosphatase in Agropyron elongatum ( $2 \mathrm{n}=2 \mathrm{x}=14, \mathrm{EE})$. Acta Genet. Sin. 25: 449-453.

Liu C, Yang ZJ, Li GR, Zeng ZX, et al. (2008). Isolation of a new repetitive DNA sequence from Secale africanum enables targeting of Secale chromatin in wheat background. Euphytica 159: 249-258.

Liu SB, Jia JZ, Wang HG, Kong LR et al. (1998). The polymorphism between Thinopyrum (Elytrigia elongatum, $2 \mathrm{n}=14$ ) and common wheat and RAPD marker specific for E genome. Acta Agron. Sin. 24: 687-690.

Ma JX, Dong YC and Jia JZ (1999). The location of wheat stripe rust resistance gene from Thinopyrum. Chin. Sci. Bull. 44: 65-69.

Ma JX, Zhou RH, Dong YS and Jia JZ (2000). Control and inheritance of resistance to yellow rust in Triticum aestivumLophopyrum elongatum chromosome substitution lines. Euphytica 111: 57-60.

Mullan DJ, Platteter A, Teakle NL, Appels R, et al. (2005). EST-derived SSR markers from defined regions of the wheat genome to identify Lophopyrum elongatum specific loci. Genome 48: 811-822.

Oliver RE, Cai X, Xu SS, Chen X, et al. (2005). Wheat-alien species derivatives: a novel source of resistance to Fusarium head blight in wheat. Crop Sci. 45: 1353-1360.

Omielan JA, Epstein E and Dvorák J (1991). Salt tolerance and ionic relations of wheat as affected by individual chromosomes of salt-tolerant Lophopyrum elongatum. Genome 34: 961-974.

Prins R, Marais GF, Pretorius ZA, Janse BJH, et al. (1997). A study of modified forms of the Lr19 translocation of common wheat. Theor. Appl. Genet. 95: 424-430.

Reynolds MP, Calderini DF, Condon AG and Rajaram S (2001). Physiological basis of yield gains in wheat associated with the Lr19 translocation from Agropyron elongatum. Euphytica 119: 139-144.

Roundy BA (1985). Root penetration and shoot elongation of tall wheatgrass and basin wildrye in relation to salinity. Can. J. Plant Sci. 65: 335-343.

Sharma D and Knott DR (1966). The transfer of leaf rust resistance from Agropyron to Triticum by irradiation. Can. J. Genet. Cytol. 8: 137-143.

Sharma H, Ohm H, Goulart L, Lister R, et al. (1995). Introgression and characterization of barley yellow dwarf virus resistance from Thinopyrum intermedium into wheat. Genome 38: 406-413.

Sharma HC, Ohm HW, Lister RW, Foster JE, et al. (1989). Response of wheatgrasses and wheat $\times$ wheatgrass hybrids to barley yellow dwarf virus. Theor. Appl. Genet. 77: 369-374.

Shen X and Ohm H (2006). Fusarium head blight resistance derived from Lophopyrum elongatum chromosome 7E and its augmentation with Fhb1 in wheat. Plant Breed. 125: 424-429.

Shen XR and Ohm H (2007). Molecular mapping of Thinopyrum-derived Fusarium head blight resistance in common wheat. Mol. Breed. 20: 131-140.

Shen X, Kong L and Ohm H (2004). Fusarium head blight resistance in hexaploid wheat (Triticum aestivum)-Lophopyrum genetic lines and tagging of the alien chromatin by PCR markers. Theor. Appl. Genet. 108: 808-813.

Shukle RH, Lampe DJ, Lister RM and Foster JE (1987). Aphid feeding behavior: relationship to barley yellow dwarf virus resistance in Agropyron species. Phytopathology 77: 725-729.

Vaillancourt A, Nkongolo KK, Michael P and Mehes M (2008). Identification, characterisation, and chromosome locations of rye and wheat specific ISSR and SCAR markers useful for breeding purposes. Euphytica 159: 297-306.

Wu M, Zhang JP, Wang JC, Yang XM, et al. (2010). Cloning and characterization of repetitive sequences and development of SCAR markers specific for the P genome of Agropyron cristatum. Euphytica 172: 363-372.

Yang ZJ and Ren ZL (2001). Chromosomal distribution and genetic expression of Lophopyrum elongatum (Host) A. Löve genes for adult plant resistance to stripe rust in wheat background. Genet. Resour. Crop. Evol. 48: 183-187.

Genetics and Molecular Research 11 (2): 1741-1751 (2012)

CFUNPEC-RP www.funpecrp.com.br 
You MS, Li BY, Tian ZH, Tang CH, et al. (2003). Development of specific SSR marker for Ee-genome of Thinopyrum sp. by using wheat microsatellites. J. Agri. Biotec. 11: 577-581.

Zhang Li, Yan ZH, Zheng YL, Liu DC, et al. (2008). Development of Ee-chromosome specific AFLP and STS molecular marker for Lophopyrum elongatum in Chinese Spring Wheat Background. J. Agri. Biotec. 16: 465-473.

Zhang X, Shen X, Hao Y, Cai J, et al. (2011). A genetic map of Lophopyrum ponticum chromosome 7E, harboring resistance genes to Fusarium head blight and leaf rust. Theor. Appl. Genet. 122: 263-270. 